\title{
Pathogen Reduction in Closed Aquaculture Systems by UV Radiation: Fact or Artifact?*
}

\author{
Stephen Spotte ${ }^{1}$ and Gary Adams ${ }^{2}$ \\ ${ }^{1}$ Sea Research Foundation, Inc., Mystic Marinelife Aquarium, Mystic, Connecticut 06355, USA \\ 2 Department of Mathematics and Physics, Thames Valley State Technical College, Norwich, Connecticut 06360, USA
}

\begin{abstract}
Differential equations were used to set a theoretical upper limit for the efficacy of UV radiation in 3 hypothetical aquaculture systems: (a) a plug-flow system, (b) an idealized closed system with no influx of pathogens, and (c) a conventional closed system in which the influx of pathogens is continuous. The equations demonstrate that, in a conventional closed system, the mass of pathogens never reaches zero even if the UV sterilizer is $100 \%$ effective. This suggests that agents such as UV radiation, which do not form persistent residuals, may be incapable of preventing the spread of waterborne pathogens in systems that are recirculated. Use of UV radiation in aquaculture is most effective in sterilization of raw water supplies and discharges into receiving waters, both of which are singlepass applications.
\end{abstract}

\section{INTRODUCTION}

Sterilizing agents commonly are used in aquaculture installations, fish hatcheries, and public aquariums, in which crowded conditions often hasten the spread of transmissible diseases. Diseases produced by singlecelled organisms, or multicellular organisms that do not require vectors, are particularly troublesome in closed systems, because all water is reused, rather than diluted continuously with clean influent. Free-floating infectious organisms (referred to here simply as pathogens) accumulate, unless the sterilization rate equals or exceeds the rate of contamination.

\section{METHOD}

We used differential equations to model the performance of UV sterilization in 3 hypothetical water systems illustrated in Fig. 1. The curves in Fig. 2 show the mass of pathogens remaining in the systems after sterilization. The effective kill rate on contact in the sterilizer was presumed to be $100 \%$ for each of the 3 schemes. Scheme A of Fig. 1 and Curve A of Fig. 2 show the total mass of pathogens remaining if water flows through the sterilizer in a single pass into a

- Contribution No. 22, Sea Research Foundation, Inc. second tank with no replacement water (plug-flow system). Scheme B of Fig. 1 and Curve B of Fig. 2 illustrate a system in which sterile water is returned from the UV unit to the culture facility with complete mixing, but without the influx of additional pathogens (idealized closed system). Scheme $C$ of Fig. 1 and Curve $C$ of Fig. 2 represent a conventional closed system; that is, water returned from the sterilizer is disease-free, but the influx of pathogens from within the culture facility itself is constant. The percent kill of pathogens in Scheme $C$ is limited by an equilibrium level at which the kill rate equals the rate of influx. This equilibrium equals the rate of influx divided by the flow rate through the sterilizer. The efficacy of the sterilizer depends on only 2 factors: the rate at which pathogens are introduced and the effectiveness of the treatment device, as shown in the equations below. The same equations can be used to calculate the rate at which chemical contaminants are removed by physical adsorption contactors, such as foam fractionators and activated carbon beds.

Symbols: $V=$ total volume of the system (constant); $\mathrm{C}_{\mathrm{o}}=$ initial mass of pathogens (constant) $\mathrm{t}_{\mathrm{o}}=$ initial time; $F=$ volume flow rate through the sterilizer (constant); $\mathrm{C}=$ mass of pathogens; $\frac{\mathrm{FC}}{\mathrm{V}}=$ kill rate (mass per unit time); $\mathrm{R}=$ influx of pathogens (mass per unit timel 


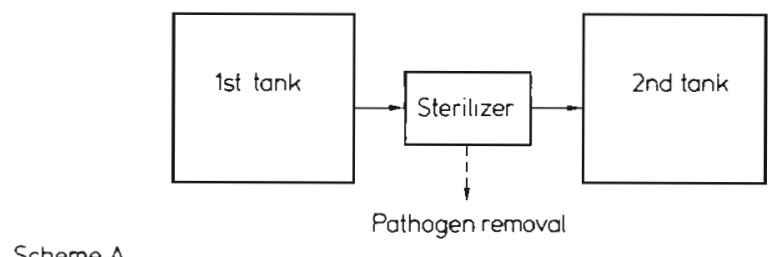

Scheme A

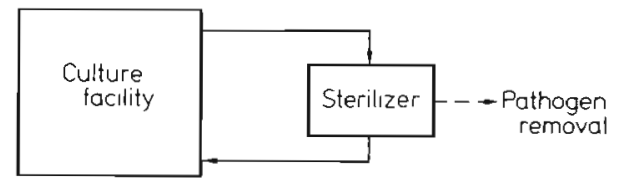

Scheme B

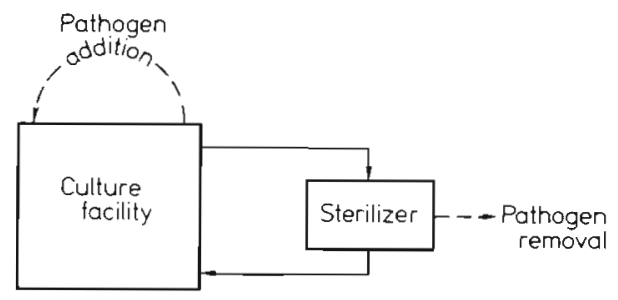

Scheme C

Fig. 1. Plug-flow system (Scheme A): water flows through the sterilizer in a single pass, and pathogens are removed at a constant rate. Idealized closed system (Scheme B): all water is recycled, there is no new addition of pathogens, and organisms are removed at a rate proportional to concentration. Conventional closed system (Scheme C): all water is recycled, pathogens are added at a constant rate, and removed at a rate proportional to concentration. The rate of sterilization at all 3 contact sites is assumed to be $100 \%$

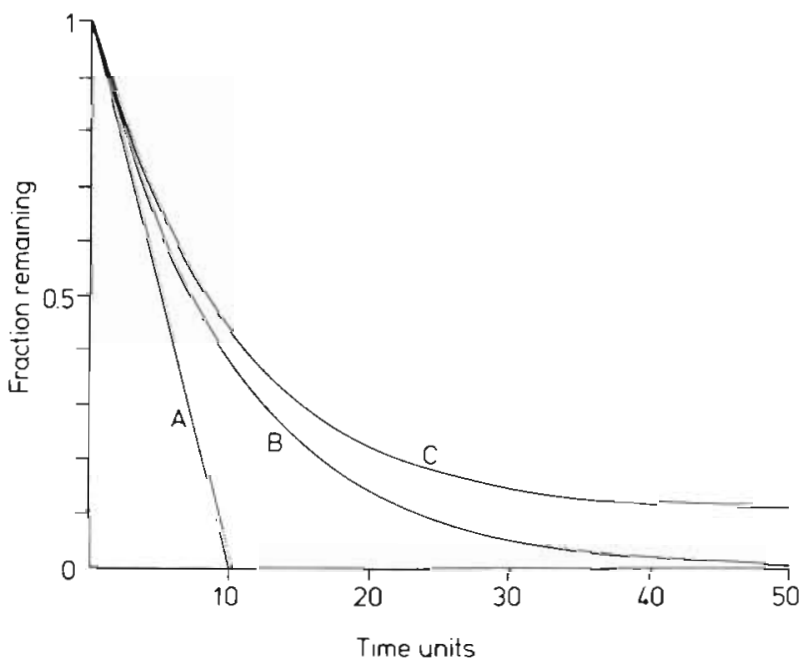

Fig. 2. Mass of pathogens remaining in Schemes A through C (Fig. 1) versus time. In closed systems (Scheme C), complete sterilization is unattainable

\section{Scheme A}

In Scheme A, water is pumped through the sterilizer on a single pass and discharged into a second tank. No water is recycled. If $\mathrm{F}=0.1 \mathrm{~V} \quad 10 \%$ of the system volume $\mathrm{h}^{-1}$, it would take $9 \mathrm{~h}$. to kill $90 \%$ of the pathogens in the system.

\section{Scheme B}

In Scheme B, all water is recycled through the sterilizer and returned continuously to the main portion of the system. There is no new influx of pathogens. Thus

$$
\begin{aligned}
& \mathrm{dC}=-\mathrm{C}\left(\frac{F}{\mathrm{~V}}\right) \mathrm{dt} \\
& \frac{\mathrm{dC}}{\mathrm{C}}=-\left(\frac{F}{\mathrm{~V}}\right) \mathrm{dt} \\
& \ln \mathrm{C}=\frac{-F}{\mathrm{~V}} \mathrm{t}+\mathrm{k} \\
& \text { at } \mathrm{t}_{0}=0, \mathrm{C}=\mathrm{C}_{0} \\
& \ln \mathrm{C}_{0}=\mathrm{k}
\end{aligned}
$$

Therefore

$$
\ln \frac{\mathrm{C}}{\mathrm{C}_{0}}=-\frac{\mathrm{Ft}}{\mathrm{V}}
$$

and

$$
\mathrm{C}=\mathrm{C}_{0} \mathrm{e}^{\frac{-F t}{v}}
$$

If $F=0.1 \mathrm{~V}$ per unit time

and

$$
\mathrm{C}=\mathrm{C}_{\mathrm{o}} \mathrm{e}^{-0.1 \mathrm{t}}
$$

$$
\begin{aligned}
& C=0.1 C_{o}(90 \% \mathrm{kill}) \\
& e^{-0.11}=0.1
\end{aligned}
$$

then

$$
\mathrm{t} \quad=23 \text { time units }
$$

For a flow through the sterilizer equal to $10 \%$ of the volume of the system per hour, $23 \mathrm{~h}$ are required to kill $90 \%$ of the pathogens.

\section{Scheme C}

In Scheme $C$, all water is recycled through the sterilizer and returned continuously to the original source, as in Scheme B. However, there also is a continuous influx of pathogens at rate $R$, and

$$
\begin{aligned}
& d C=-C\left(\frac{F}{V}\right) d t+R d t \\
& d C=\left[-C\left(\frac{F}{V}\right)+R\right] d t
\end{aligned}
$$


Integration yields

$$
C=e^{\frac{-F}{V}}\left(C_{0}-\frac{R V}{F}\right)+\frac{R V}{F}
$$

If $F=0.1 \mathrm{~V}$ and $\mathrm{R}=0.01$ for a $90 \%$ kill, $C=0.1 \mathrm{C}_{\mathrm{o}}$, then because

in this case

$$
C=e^{\frac{-F}{V}}\left(C_{0}-\frac{R V}{F}\right)+\frac{R V}{F}
$$

$$
C=0.9 \mathrm{C}_{0} \mathrm{e}^{-0.11}+0.1
$$

By substituting different values for tit can be shown that a $90 \%$ kill can be attained only after infinite time. In fact, the mass of pathogens remaining cannot be less than $\frac{R V}{F}$, which in this case is $10 \%$ of $C_{0}$.

\section{DISCUSSION}

As noted by Herald et al. (1970), the effectiveness of UV radiation is limited to in vitro situations; in other words, to the destruction of pathogens that are freefloating in the water. Organisms that are systemic, or attached to exterior surfaces of their hosts, are unaffected and can only be controlled chemotherapeutically. Organisms shed into the water, or which detach from their hosts, thus represent a reservoir of contamination that cannot be eliminated from closed systems, if sterilization occurs at a single contact site (Scheme C).

Spotte (1979) reviewed the use of UV radiation in aquatic animal culture. Some pathogens always survive, despite kill rates that sometimes approach $100 \%$ at the contact site. Animals maintained in closed systems thus are subject to possible reinfection from water returning from the sterilizer, the degree of reinfection depending on the virulence and concentration of the pathogen and the immune status of the host. Bullock and Stuckey (1977) studied the effect of UV radiation on bacterial counts of salmonid hatchery water. In some instances, bacteria at the contact site were reduced $99.99 \%$, but the authors cautioned against placing undue emphasis on the results, because the number of bacteria necessary to transmit disease is difficult to predict. They pointed out that, in their experiments, a $99.99 \%$ kill of a pathogen at a cell density of $10^{4} \mathrm{ml}^{-1}$ would leave only $1.0 \mathrm{ml}^{-1}$. They concluded that even this low concentration might be adequate to transmit disease during intensive culture if the pathogen is virulent, considering the growth potential of bacteria. Buck (1980) recorded low cell densities of a variety of potentially pathogenic fungi in a UV-treated marine mammal pool operated as a closed system. Spotte and Buck (1981) studied the efficacy of UV sterilization on pathogen reduction in the same pool. They observed that cutaneous and systemic infections in the captive dolphins and whales. caused by the yeast Candida albicans, continued to flourish even though cell counts never exceeded 100 $1^{-1}$ anywhere in the water system.

Disease-causing organisms can also be transmitted among cultured animals directly, short-circuiting the sterilizer completely (Scheme C). The result may be a high percent kill at the contact site that is not accompanied by a concomitant decrease in the incidence of disease or mortality. For example, Herald et al. (1970) reported that mortality rates among exhibit fishes at a public aquarium were unchanged by installation of a UV sterilizer that lowered the total bacteria at the contact site by $98 \%$. Spanier (1978) noted that mortality rates of bream (Sparus aurata) larvae were unaffected by UV sterilization of the recycled water, despite a substantial decrease in bacterial counts at the sterilizer effluent.

The application of UV radiation in the treatment of raw influent water is effective in lowering the numbers of pathogens and thus reducting the chances of disease organisms entering from external sources (Stickney and White, 1974; Hoffmann, 1975; Kimura et al., 1976; Blogoslawski et al., 1978; Brown and Russo, 1979). Results derived from this application can be considered $\mathrm{f} a \mathrm{ct}$. If the water is recycled, however, any apparent efficacy of a UV sterilizer, based on kill rate, is an a r if a c t, because the mass of pathogens in the immediate vicinity of the cultured animals is always greater than the mass in the sterilizer effluent. Equilibrium is never attained, and the entire system cannot be rendered disease-free, even when the sterilization process is $100 \%$ effective.

In conclusion, UV sterilization should perhaps be limited to the treatment of influent water supplies, or to the final effluent from culture installations before it is discharged into receiving waters. Both are single-pass applications, for which the effectiveness of UV treatment is well documented.

Acknowledgements. We wish to thank James W. Atz, Carol E Bower, Walter J. Blogoslawski, John B. Gratzek, and Gary D Pruder for their reviews of the manuscript.

\section{LITERATURE CITED}

Blogoslawski, W. J., Stewart, M. E., Rhodes, E. W (1978). Bacterial disinfection in shellfish hatchery disease control. Proc. World Maricult. Soc. 9: 589-602

Brown, C., Russo, D. J. (1979). Ultraviolet light disinfection of shellfish hatchery sea water. I. Elimination of five pathogenic bacteria. Aquaculture 17: 17-23

Buck, J. D. (1980). Occurrence of human-associated yeasts in the feces and pool waters of captive bottlenosed dolphins (Tursiops truncatus). J. Wildl. Dis. 16: 141-149

Bullock, G. L.. Stuckey, H. M. (1977). Ultraviolet treatment of water for destruction of five gram-negative bacteria pathogenic to tishes. J. Fish. Res. Bd Can. 34: 1244-1249 
Herald, E. S., Dempster, R. P., Hunt, M. (1970). Ultraviolet sterilization of aquarium water. In: Hagen, W. (ed.) Aquarium design criteria. (Spec. ed.). Drum and Croaker, $\mathrm{U}$. S. Department of the Interior, Washington, $D C, p p$. $57-71$

Hoffman, G. L. (1975). Whirling disease (Myxosoma cerebralis): Control with ultraviolet irradiation and effect on fish. J. Wildl. Dis. 11: 505-507

Kimura, T., Yoshimizu, M., Tajima, K., Ezura, Y., Sakai, M. (1976). Disinfection of hatchery water supply by ultraviolet (U. V.) irradiation. I. Susceptibility of some fish-pathogenic bacterium and microorganisms inhabiting pond waters. Bull. Jap. Soc. Sci. Fish. 42: 207-211

Spanier, E. (1978). Preliminary trials with an ultraviolet liquid sterilizer. Aquaculture 14: 75-84

Spotte, S. (1979). Seawater aquariums: The captive environment, Wiley, New York

Spotte, S., Buck, J. D. (1981). The efficacy of UV irradiation in the microbial disinfection of marine mammal water $J$. Wildl. Dis. 17: 11-16

Stickney, R. R., White, D. B. (1974). Lymphocystis in tankcultured flounder. Aquaculture 4: 307-308

This paper was submitted to the editor; it was accepted for printing on July 23, 1981 